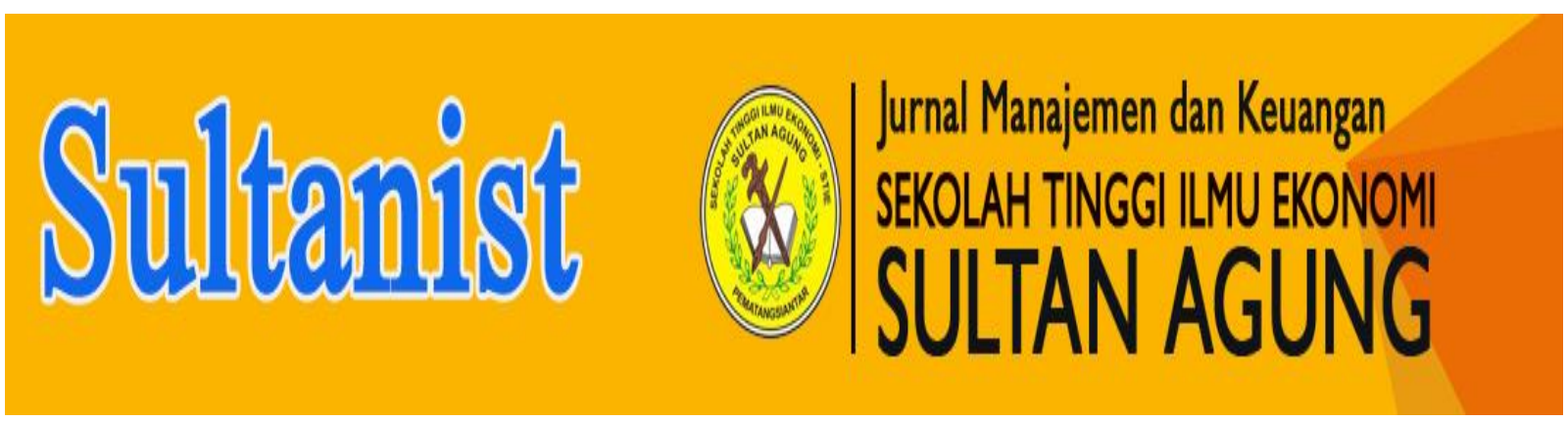

\title{
ANALISIS LIKUIDITAS, SOLVABILITAS DAN KEBIJAKAN DIVIDEN DAPAT MENINGKATKAN NILAI PERUSAHAAN PADA PT KEBELINDO MURNI,TbK YANG TERDAFTAR DI BURSA EFEK INDONESIA
}

\author{
Oleh : \\ Demak Aldi Pardede \\ Sarjana Akuntansi \\ Jubi, Ady Inrawan, Juan Anastasia Putri
}

Abstrak

Tujuan penelitian ini adalah: 1. Untuk mengetahui gambaran likuiditas, solvabilitas, kebijakan dividen dan nilai perusahaan pada PT Kabelindo Murni, Tbk yang terdaftar di Bursa Efek Indonesia. 2. Untuk mengetahui faktor-faktor apa yang menyebabkan nilai perusahaan pada PT Kabelindo Murni, Tbk meningkat.

Penelitian penulis dilakukan dengan menggunakan teknik analisis deskriptif kualitatif, teknik analisis komparatif dan teknik analisis induktif. Jenis data dalam penelitian adalah data kualitatif dan data kuantitatif. Sumber data yang digunakan adalah data sekunder. Pengumpulan data dalam penelitian adalah teknik dokumentasi.

Hasil dari penelitian ini disimpulkan 1. Nilai rata-rata likuiditas dengan parameter Current Ratio (CR) mengalami fluktuasi dan cenderung meningkat, namun peningkatan aset lancar diikuti analisis dengan penurunan nilai kewajiban lancar. 2. Nilai rata-rata solvabilitas dengan parameter Debt to Asset Ratio (DAR) mengalami fluktuasi dan cenderung menurun, Hal ini disebabkan penurunan hutang yang lebih tinggi daripada penurunan total aset perusahaan. 3. Kebijakan Dividen (DPR) mengalami fluktuasi dan cenderung meningkat $\mathrm{Hal}$ ini disebabkan oleh peningkatan dividen per lembar saham sementara terjadi penurunan laba per lembar saham. 4. Nilai perusahaan dengan parameter PBV mengalami fluktuasi dan cenderung meningkat, hal ini disebabkan peningkatan harga saham lebih tinggi daripada peningkatan nilai buku per lembar saham.

Saran penelitian ini adalah : Sebaiknya perusahaan menambahkan modal kerja dengan cara melakukan hutang jangka panjang untuk membeli persediaan yang dapat meningkatkan penjualan, sebaiknya perusahaan meningkatkan penjualan dan mengurangi beban operasional agar laba yang didapat meningkat dan meningkatnya laba dapat meningkatkan EPS sehingga DPR dapat dikendalikan, sebaiknya perusahaan meningkatkan laba dengan cara meningkatkan penjualan dan mengefisiensikan beban operasi. Laba yang menigkat dapat digunakan sebagai modal kerja perusahaan.

Kata Kunci : Analisis Likuiditas, Solvabilitas, Kebijakan Dividen dan Nilai Perusahaan

\section{Abstract}

The purpose of this study are: 1. To find out an overview of liquidity, solvency, dividend policy and company value in PT Kabelindo Murni, Tbk, which is listed on the Indonesia Stock Exchange. 2. To find out what factors cause company value in PT Kabelindo Murni, Tbk to increase.

The author's research was conducted using qualitative descriptive analysis techniques, comparative analysis techniques and inductive analysis techniques. The type of data in the study are qualitative data and quantitative data. The data source used is secondary data. Data collection in research is documentation techniques.

The results of this study concluded 1. The average value of liquidity with the parameter Current Ratio (CR) fluctuates and tends to increase, but the increase in current assets was followed by an analysis with a decrease in the value of current liabilities. 2. The average solvency value with the parameters Debt to Asset Ratio (DAR) fluctuates and tends to decrease, this is due to a decrease in debt which is higher than the decrease in the total assets of the company. 3. Dividend Policy (DPR) experienced fluctuations and tended to increase. This was caused by an increase in dividends per share while there was a decrease in earnings per share. 4. The company value with PBV parameters fluctuates and tends to increase, this is due to an increase in stock prices higher than the increase in book value per share.

Suggestions for this research are: It is better for companies to add working capital by making long-term debt to buy inventory that can increase sales, it is best for companies to increase sales and reduce operating expenses so that profits can increase and increasing profits can increase EPS so that the DPR can be controlled, it is best for companies to increase profits by increasing sales and streamlining operating expenses. Increasing profit can be used as working capital of the company.

Keywords : Liquidity Analysis, Solvability, Dividend Policy and Company Value. 


\section{PENDAHULUAN}

\subsection{Latar Belakang Masalah}

Nilai perusahaan sangat penting karena mencerminkan kinerja keuangan yang dapat mempengaruhi penilaian para investor terhadap perusahaan. . Nilai perusahaan yang tinggi akan menciptakan harga saham yang tinggi. Salah satu rasio yang digunakan untuk mengukur nilai perusahaan dengan menggunakan Price to Book Value (PBV).

Naik turunnya suatu nilai perusahaan dapat dipengaruhi beberapa faktor yaitu likuiditas, solvabilitas dan kebijakan dividen. Likuiditas adalah kemampuan suatu perusahaan untuk melunasi liabilitasnya, terutama liabilitas jangka pendek dengan menggunakan aktiva lancar. Solvabilitas adalah kemampuan perusahaan untuk membayar seluruh kewajibannya, baik jangka pendek maupun jangka panjang. Sedangkan Kebijakan dividen adalah keputusan untuk membagi laba atau menahannya guna diinvestasikan kembali di dalam perusahaan.

Berikut ini adalah gambaran likuiditas, solvabilitas, kebijakan dividen dan nilai perusahaan pada PT Kabelindo Murni, Tbk yang Terdaftar di Bursa Efek Indonesia periode 2012-2016 pada Tabel 1.1

Tabel 1.1

Rata-rata Likuiditas, Solvabilitas, Kebijakan

Dividen dan Nilai Perusahaan pada PT

Kabelindo Murni, Tbk yang terdaftar di Bursa Efek Indonesia Periode 2012-2016

\begin{tabular}{|c|c|c|c|c|}
\hline Tahun & $\begin{array}{c}\text { CR } \\
\text { (Kali) }\end{array}$ & DAR (Kali) & DPR (Kali) & $\begin{array}{c}\text { PBV } \\
\text { (Kali) }\end{array}$ \\
\hline 2012 & 0,98 & 0,63 & 0,14 & 0,57 \\
\hline 2013 & 0,96 & 0,59 & 0,43 & 0,66 \\
\hline 2014 & 1,04 & 0,55 & 0,17 & 0,60 \\
\hline 2015 & 1,06 & 0,55 & 0,45 & 0,50 \\
\hline 2016 & 1,30 & 0,50 & 0,16 & 0,84 \\
\hline $\begin{array}{c}\text { Rata- } \\
\text { Rata }\end{array}$ & $\mathbf{1 , 0 7}$ & $\mathbf{0 , 5 6}$ & $\mathbf{0 , 2 7}$ & $\mathbf{0 , 6 3}$ \\
\hline
\end{tabular}

Sumber: data diolah

Dari tabel 1.1, dapat dilihat bahwa Pada tahun 2013 sampai tahun 2015 nilai likuiditas (CR) mengalami peningkatan akan tetapi nilai perusahaan (PBV) mengalami penurunan. Pada tahun 2016 nilai solvabilitas dengan parameter debt to asset ratio (DAR) mengalami penurunan sementara nilai perusahaan (PBV) tahun 2016 mengalami peningkatan. Pada tahun 2016 Kebijakan dividen dengan parameter Debt Payout Ratio (DPR) mengalami penurunan namun nilai perusahaan pada tahun 2016 mengalami peningkatan.

\subsection{Rumusan Masalah}

1. Bagaimana gambaran likuiditas, solvabilitas, kebijakan dividen dan nilai perusahaan pada PT Kabelindo Murni, Tbk yang terdaftar di Bursa Efek Indonesia.
2. Faktor-faktor apa yang menyebabkan nilai perusahaan pada PT Kabelindo Murni, Tbk meningkat.

\subsection{Tujuan Penelitian}

1. Untuk mengetahui gambaran likuiditas, solvabilitas, kebijakan dividen dan nilai perusahaan pada PT Kabelindo Murni, Tbk yang terdaftar di Bursa Efek Indonesia.

2. Untuk mengetahui faktor-faktor apa yang menyebabkan nilai perusahaan pada PT Kabelindo Murni, Tbk meningkat.

\subsection{Metodologi Penelitian}

Penelitian ini menggunakan data sekunder dengan cara mengakses dari situs http://www.idx.co.id. Desain penelitian ini adalah penelitian kepustakaan (library research). Teknik analisis data yang digunakan penulis dalam penelitian ini seperti analisis deskriptif kualitatif, Teknik Analisis Trend dan Teknik Analisis Induktif.

\section{LANDASAN TEOR}

\subsection{Akuntansi}

Akuntansi merupakan informasi keuangan yang digunakan dalam pengambilan keputusan perusahaan yang dibutuhkan oleh manajemen atau pemakai lain. Menurut pendapat Soemarso (2004:3), "akuntansi merupakan proses mengidentifikasi, mengukur, dan melaporkan informasi, untuk dilakukannya penilaian dan keputusan". Sedangkan menurut Mursyidi (2010:17), "akuntansi merupakan proses pengidentifikasian data keuangan, memproses pengolahan dan penganalisaan data yang dijadikan dalam pembuatan keputusan". Dan menurut Rudianto (2009:4), "akuntansi adalah sistem informasi yang menghasilkan informasi keuangan kepada pihak-pihak yang berkepentingan mengenai aktifitas ekonomi dan kondisi suatu perusahaan".

\subsection{Analisa Laporan Keuangan}

Analisa laporan keuangan menjadi sangat penting untuk dilakukan, karena dengan menggunakannya maka para pengguna dapat mengetahui kekuatan dan kelemahan dari suatu perusahaan. Menurut Astuti (2004:29), "analisis laporan keuangan adalah segala sesuatu yang menyangkut penggunaan informasi akuntansi untuk membuat keputusan bisnis dan investasi".

Sedangkan menurut Rudianto (2013:190), "analisis laporan keuangan adalah meneliti hubungan yang ada antara unsur-unsur dalam laporan keuangan, dan membandingkan unsur-unsur pada laporan keuangan tahun 
berjalan dengan unsur-unsur yang sama tahun lalu atau angka pembanding lain serta menjelaskan penyebab perubahannya".

Selain itu menurut Subramanyam dan John (2010:4), "analisa laporan keuangan (financial statement analysis) adalah aplikasi dari alat dan teknik analisis untuk laporan keuangan bertujuan umum dan data-data yang berkaitan untuk menghasilkan data estimasi dan kesimpulan yang bermanfaat dalam analisis bisnis"

\subsection{Rasio Keuangan}

Rasio keuangan digunakan agar dapat membantu mengevaluasi laporan keuangan. Rasio keuangan penting dilakukan untuk mengetahui kekuatan dan kelemahan suatu perusahaan serta untuk memperlihatkan hubungan antara akun pada laporan keuangan. Menurut Horne dan John (2012:163), "rasio keuangan adalah indeks yang menghubungkan dua angka akuntansi dan diperoleh dengan membagi satu angka dengan angka lainnya". Menurut Astuti (2004:29), "rasio keuangan adalah penggunaan informasi akuntansi yang dirancang untuk membantu mengevaluasi laporan keuangan". Sementara menurut Kasmir (2010:104), "rasio keuangan merupakan kegiatan membandingkan angkaangka yang ada dalam laporan keuangan dengan cara membagi satu angka lainnya".

\subsection{Likuiditas}

Likuiditas merupakan kemampuan suatu perusahaan dalam memenuhi liabilitas jangka pendeknya dengan tepat waktu. Menurut Murhadi (2013:56), "likuiditas adalah kemampuan perusahaan dalam memenuhi liabilitas jangka pendeknya". Sedangkan menurut Brigham dan Joel (2011:179), "likuiditas adalah kemampuan perusahaan dalam menunjukkan hubungan kas dan aktiva lancar lainnya dengan dengan kewajiban lancar". Selain itu menurut Munawir (2004:31), "likuiditas adalah kemampuan suatu perusahaan untuk memenuhi kewajiban keuangannya yang harus segera dipenuhi, atau kemampuan perusahaan untuk memenuhi kewajiban keuangan dapa saat ditagih".

\subsection{Solvabilitas}

Untuk mengukur seberapa besar beban hutang yang akan ditanggung perusahaan dalam rangka pemenuhan asset, rasio yang dapat digunakan adalah rasio solvabilitas. Menurut Kasmir (2015:151), "rasio solvabilitas digunakan untuk mengukur kemampuan perusahaan untuk membayar seluruh kewajibannya, baik jangka pendek maupun jangka panjang apabila perushaan dibubarkan (dilikuidasi)".
Menurut Riyanto (2009:32), "pengertian solvabilitas dimaksudkan sebagai kemampuan suatu perusahaan untuk membayar semua utang-utangnya (baik jangka panjang maupun jangak pendek). Suatu perusahaan yang solvable berarti suatu perusahaan yang mempunyai aktiva atau kekayaan yang cukup untuk membayar semua utang-utangnya". Sedangkan menurut Hery (2015:190), "rasio solvabilitas atau rasio leverage merupakan rasio yang digunakan untuk mengukur sejauh mana aset perusahaan dibiayai dengan utang.

Pertumbuhan perusahaan merupakan kemampuan perusahaan untuk meningkatkan ukuran perusahaan melalui peningkatan aktiva. Pertumbuhan perusahaan tahun sebelumnya digunakan untuk meramalkan pertumbuhan perusahaan pada tahun berikutnya.

Menurut Atmaja (2008:274), "perusahaan yang tinggi tingkat pertumbuhannya pada umumnya tergantung pada modal dari luar perusahaan. Pada perusahaan dengan tingkat pertumbuhan yang rendah, kebutuhan baru relatif kecil sehingga dapat dipenuhi dari laba ditahan". Selain itu, menurut Brigham dan Joel (2011:189), "perusahaan yang memiliki pertumbuhan lebih cepat harus lebih mengandalkan diri pada modal eksternal".

Sedangkan menurut Murhadi (2013:93), "ada tiga cara untuk mengestimasi pertumbuhan perusahaan, yaitu menggunakan rata-rata pertumbuhan historis, mempercayai pihak analisis riset saham yang selalu mengikuti perkembangan perusahaan, dan seberapa besar dana yang di reinvestasikan dalam pusat aset baru serta bagaimana kualitas aset tersebut".

\subsection{Kebijakan Dividen}

Kebijakan dividen adalah hal yang tidak terpisahkan dalam keputusan pendanaan perusahaan yang berupa dividen atau biasanya ditahan guna sebagai laba yang ditahan untuk pembiayaan investasi dimasa yang akan datang yang akan dibagikan kepada pemegang saham. Menurut Sudana (2011:145), "kebijakan dividen adalah bagian dari keputusan pembelanjaan perusahaan, khususnya berkaitan dengan internal perusahaan".

Selain itu menurut Horne dan John (2013:206), "kebijakan dividen dalah bagian yang tak terpisahkan dalam keputusan pendanaan perusahaan. Rasio pembayaran dividen (dividend payout ratio) menentukan jumlah saldo laba dalam perusahaan sebagai sumber pendanaan". Sedangkan menurut Astuti (2004:145), "kebijakan dividen adalah menyangkut keputusan untuk membagi laba atau menahannya guna diinvestasikan kembali di dalam perusahaan". 


\subsection{Nilai Perusahaan}

Nilai perusahaan merupakan sebuah persepsi para investor terhadap sebuah perusahaan yang sering dikaitkan dengan harga saham. Bila harga saham yang tinggi maka akan membuat nilai perusahaan juga tinggi. Menurut Brigham dan Joel (2012:151), "rasio harga pasar suatu saham terhadap nilai bukunya memberikan indikasi pandangan investor atas perusahaan". Perusahaan yang dipandang baik oleh investor adalah perusahaan laba dan harus kas yang aman, serta terus mengalami pertumbuhan. Menurut Keown, et.al. (2008:470), "nilai perusahaan adalah nilai pasar surat berharga pada utang dan ekuitas perusahaan yang beredar". Nilai ini ditentukan oleh kekuatan penawaran dan permintaan pasar. Sedangkan menurut Atmaja (2008:412), "nilai perusahaan merupakan perbandingan antara nilai buku dengan nilai pasaran dimana nilai buku modal mencatat uang tunai yang disetor oleh pemegang saham dimasa lalu ditambah uang tunai dana laba ditahan"

\section{PEMBAHASAN}

3.1. Analisis

3.1.1. Analisis Likuiditas pada PT Kabelindo Murni, Tbk yang Terdaftar di Bursa Efek Indonesia periode 2012-2016

Berikut disajikan data Likuiditas pada PT Kabelindo Murni, Tbk yang terdaftar di Bursa Efek Indonesia Periode 2012-2016 :

\section{Tabel 3.1}

Analisis Likuiditas pada PT Kabelindo

Murni, Tbk yang Terdaftar di Bursa

Efek Indonesia Periode 2012-2016

\begin{tabular}{|c|c|c|c|}
\hline Tahun & $\begin{array}{c}\text { Aktiva Lancar } \\
\text { (Rp) }\end{array}$ & $\begin{array}{c}\text { Kewajiban Lancar } \\
\text { (Rp) }\end{array}$ & $\begin{array}{c}\text { Likui } \\
\text { ditas }\end{array}$ \\
\hline 2012 & 430.524 .213 .124 & 441.527 .159 .100 & 0,98 \\
\hline 2013 & 352.670 .946 .095 & 368.703 .142 .721 & $\mathbf{0 , 9 6}$ \\
\hline 2014 & 356.748 .585 .043 & 342.700 .429 .672 & 1,04 \\
\hline 2015 & 362.277 .745 .626 & 342.643 .691 .341 & 1,06 \\
\hline 2016 & 394.738 .153 .988 & 303.264 .273 .023 & $\mathbf{1 , 3 0}$ \\
\hline \multicolumn{3}{|c|}{ Nilai Minimum } & $\mathbf{0 , 9 6}$ \\
\hline \multicolumn{3}{|c|}{ Nilai Maksimum } & $\mathbf{1 , 3 0}$ \\
\hline \multicolumn{3}{|c|}{ Nilai rata-rata } & $\mathbf{1 , 0 7}$ \\
\hline
\end{tabular}

Sumber : Data diolah

Berdasarkan Tabel 3.1 terlihat nilai likuiditas pada PT Kabelindo Murni, Tbk yang terdaftar di Bursa Efek Indonesia periode 2012-2016 mengalami fluktuasi dan cenderung meningkat. Hal ini disebabkan karena aktiva lancar dan hutang lancar mengalami penurunan, namun penurunan hutang lancar lebih tinggi daripada penurunan aktiva lancar.
3.1.2. Analisis Solvabilitas pada PT Kabelindo Murni, Tbk yang terdaftar di Bursa Efek Indonesia Periode 20122016

Berikut ini Analisis solvabilitas pada PT Kabelindo Murni, Tbk yang terdaftar di Bursa Efek Indonesia Periode 2012-2016

Tabel 3.2

Analisis Solvabilitas PT Kabelindo Murni,

Tbk yang terdaftar di Bursa Efek Indonesia Periode 2012-2016

\begin{tabular}{|c|c|c|c|}
\hline Tahun & Total Utang (Rp) & Total Aset (Rp) & DAR \\
\hline 2012 & 458.195 .274 .791 & 722.941 .339 .245 & 0,63 \\
\hline 2013 & 384.632 .097 .122 & 654.296 .256 .935 & 0,59 \\
\hline 2014 & 357.408 .981 .156 & 647.696 .854 .298 & 0,55 \\
\hline 2015 & 357.910 .337 .055 & 654.385.717.061 & 0,55 \\
\hline 2016 & 318.436 .089 .653 & 639.091.366.917 & 0,50 \\
\hline \multicolumn{3}{|c|}{ Nilai Minimum } & 0,50 \\
\hline \multicolumn{3}{|c|}{ Nilai Maksimum } & 0,63 \\
\hline \multicolumn{3}{|c|}{ Nilai rata-rata } & 0,56 \\
\hline
\end{tabular}

Sumber : Data Diolah

Berdasarkan dari Tabel 3.2 diketahui solvabilitas pada PT Kabelindo Murni, Tbk yang terdaftar di Bursa Efek Indonesia periode 2012-2016 berfluktuasi dan cenderung menurun. Hal ini disebabkan karena menurunnya total utang lebih tinggi daripada penurunan total aset.

3.1.3. Analisis Kebijakan Dividen pada PT Kabelindo Murni, Tbk yang terdaftar di Bursa Efek Indonesia Periode 20122016

Gambaran Kebijakan dividen pada PT Kabelindo Murni, Tbk yang terdaftar di Bursa Efek Indonesia Periode 2012-2016

Tabel 3.3

Analisis Kebijakan Dividen pada PT

Kabelindo Murni, Tbk yang terdaftar di Bursa Efek Indonesia Periode 2012-2016

\begin{tabular}{|c|c|c|c|c|c|}
\hline Tahun & $\begin{array}{c}\text { Dividen yang } \\
\text { dibagikan (Rp) }\end{array}$ & $\begin{array}{c}\text { Jumlah } \\
\text { Lembar } \\
\text { Saham }\end{array}$ & $\begin{array}{c}\text { Dividen } \\
\text { Per } \\
\text { lembar } \\
\text { saham }\end{array}$ & $\begin{array}{c}\text { Laba } \\
\text { per } \\
\text { Lembar } \\
\text { Saham }\end{array}$ & DPR \\
\hline 2012 & 3.360 .000 .000 & 1.120 .000 .000 & 3 & 21 & $\mathbf{0 , 1 4}$ \\
\hline 2013 & 3.360 .000 .000 & 1.120 .000 .000 & 3 & 7 & 0,43 \\
\hline 2014 & 3.360 .000 .000 & 1.120 .000 .000 & 3 & 18 & 0,17 \\
\hline 2015 & 5.600 .000 .000 & 1.120 .000 .000 & 5 & 11 & $\mathbf{0 , 4 5}$ \\
\hline 2016 & 3.360 .000 .000 & 1.120 .000 .000 & 3 & 19 & 0,16 \\
\hline \multicolumn{5}{|c|}{ Nilai Minimum } & $\mathbf{0 , 1 4}$ \\
\hline \multicolumn{5}{|c|}{ Nilai Maksimum } & $\mathbf{0 , 4 5}$ \\
\hline \multicolumn{5}{|c|}{ Nata-rata } \\
\hline
\end{tabular}
Sumber : Data Diolah

Berdasarkan Tabel 3.3 diketahui nilai kebijakan dividen pada PT Kabelindo Murni, Tbk yang terdaftar di Bursa Efek Indonesia periode 2012-2016 berfluktuasi dan cenderung meningkat. Hal ini disebabkan karena meningkatnya dividen per lembar saham, namun peningkatan dividen per lembar saham diikuti dengan penurunan laba per lembar saham 
3.1.4. Analisis Nilai Perusahaan pada PT Kabelindo Murni, Tbk yang terdaftar di Bursa Efek Indonesia Periode 20122016

Nilai Perusahaan pada PT Kabelindo Murni, Tbk yang terdaftar di Bursa Efek Indonesia Periode 2012-2016 yang diukur dengan PBV:

Tabel 3.4

Analisis Nilai Perusahaan pada PT Kabelindo Murni, Tbk yang terdaftar di Bursa Efek Indonesia Periode 2012-2016

\begin{tabular}{|c|c|c|c|c|c|}
\hline & $\begin{array}{c}\text { HARGA } \\
\text { PASAR } \\
\text { TAHUN } \\
\text { SAHAM } \\
\text { (Rp) }\end{array}$ & $\begin{array}{c}\text { EKUITAS } \\
\text { BIASA (Rp) }\end{array}$ & $\begin{array}{c}\text { JUMLAH } \\
\text { SAHAM } \\
\text { BEREDAR }\end{array}$ & $\begin{array}{c}\text { NILAI } \\
\text { BUKU } \\
\text { EKUITA } \\
\text { S PER } \\
\text { SAHAM }\end{array}$ & PBV \\
\hline 2012 & 135 & 264.337 .240 .369 & 1.120 .000 .000 & 236,02 & 0,57 \\
\hline 2013 & 158 & 268.663 .908 .620 & 1.120 .000 .000 & 239,88 & 0,66 \\
\hline 2014 & 155 & 289.350 .438 .539 & 1.120 .000 .000 & 258,35 & 0,60 \\
\hline 2015 & 132 & 295.560 .224 .716 & 1.120 .000 .000 & 263,89 & $\mathbf{0 , 5 0}$ \\
\hline 2016 & 240 & 320.249 .362 .691 & 1.120 .000 .000 & 285,94 & $\mathbf{0 , 8 4}$ \\
\hline \multicolumn{5}{|c|}{ Nilai Minimum } & $\mathbf{0 , 5 0}$ \\
\hline \multicolumn{7}{|c|}{ Nilai Maksimum } \\
\hline \multicolumn{7}{|c|}{ Nilata-rata } & $\mathbf{0 , 8 4}$ \\
\hline Sumb & $\mathbf{0 , 6 3}$ \\
\hline
\end{tabular}

Sumber : Data Diolah

Berdasarkan Tabel 3.4 diketahui nilai perusahaan pada PT Kabelindo Murni, Tbk yang terdaftar di Bursa Efek Indonesia periode 2012-2016 berfluktuasi dan cenderung meningkat. Hal ini disebabkan karena harga saham mengalami peningkatan lebih tinggi daripada peningkatan nilai buku per saham. Nilai buku perusahaan meningkat karena ekuitas biasa yang meningkat setiap tahunnya sedangkan jumlah saham yang beredar tetap jumlahnya.

3.1.5. Analisis Likuiditas dan Nilai

Perusahaan pada PT Kabelindo

Murni, Tbk yang terdaftar di Bursa

Efek Indonesia Periode 2012-2016

Berikut ini adalah analisis likuiditas dan nilai perusahaan pada PT Kabelindo Murni, Tbk yang terdaftar di Bursa Efek Indonesia Tabel 3.5

Analisis Likuiditas dan Nilai Perusahaan pada PT Kabelindo Murni, Tbk yang terdaftar di Bursa Efek Indonesia Periode 2012-2016

\begin{tabular}{|c|c|c|c|}
\hline Tahun & $\begin{array}{c}\text { Likuiditas } \\
\text { (Kali) }\end{array}$ & Tahun & $\begin{array}{c}\text { Nilai Perusahaan } \\
\text { (Kali) }\end{array}$ \\
\hline 2012 & 0,98 & 2012 & 0,57 \\
\hline 2013 & 0,96 & 2013 & 0,66 \\
\hline 2014 & $\mathbf{1 , 0 4}$ & 2014 & $\mathbf{0 , 6 0}$ \\
\hline 2015 & $\mathbf{1 , 0 6}$ & 2015 & $\mathbf{0 , 5 0}$ \\
\hline 2016 & 1,30 & 2016 & 0,84 \\
\hline
\end{tabular}

Sumber : Data Diolah

Berdasarkan dari Tabel 3.5 diketahui bahwa nilai likuiditas pada PT Kabelindo Murni,Tbk yang terdaftar di Bursa Efek Indonesia periode 2012-2016 mengalami fluktuasi dan cenderung meningkat dan nilai perusahaan juga mengalami peningkatan. Nilai likuiditas pada tahun 2014-2015 mengalami peningkatan namun di tahun tersebut juga nilai perusahaan mengalami penurunan.

3.1.6. Analisis Solvabilitas dan Nilai Perusahaan pada PT Kabelindo Murni, Tbk yang terdaftar di Bursa Efek Indonesia Periode 2012-2016

Berikut ini adalah analisis Solvabilitas dan nilai perusahaan pada PT Kabelindo Murni, Tbk yang terdaftar di Bursa Efek Indonesia

Tabel 3.6

Analisis Solvabilitas dan Nilai Perusahaan pada PT Kabelindo Murni, Tbk yang terdaftar di Bursa Efek Indonesia Periode 2012-2016

\begin{tabular}{|c|c|c|c|}
\hline Tahun & $\begin{array}{c}\text { Solvabilitas } \\
\text { (Kali) }\end{array}$ & Tahun & $\begin{array}{c}\text { Nilai Perusahaan } \\
\text { (Kali) }\end{array}$ \\
\hline 2012 & 0,63 & 2012 & 0,57 \\
\hline 2013 & 0,59 & 2013 & 0,66 \\
\hline 2014 & 0,55 & 2014 & 0,60 \\
\hline 2015 & 0,55 & 2015 & 0,50 \\
\hline 2016 & $\mathbf{0 , 5 0}$ & 2016 & $\mathbf{0 , 8 4}$ \\
\hline
\end{tabular}

Sumber : Data Diolah

Berdasarkan Tabel 5.6 terlihat ratarata solvabilitas pada PT Kabelindo Murni, Tbk periode 2012-2016 berfluktuasi dan cenderung menurun. Diketahui bahwa nilai solvabilitas pada PT Kabelindo Murni,Tbk yang terdaftar di Bursa Efek Indonesia periode 2012-2016 mengalami fluktuasi dan cenderung menurun namun pada di tahun tersebut nilai perusahaan mengalami peningkatan.

\subsubsection{Analisis Kebijakan Dividen dan Nilai} Perusahaan pada PT Kabelindo Murni, Tbk yang terdaftar di Bursa Efek Indonesia Periode 2012-2016

Berikut ini adalah analisis Solvabilitas dan nilai perusahaan pada PT Kabelindo Murni, Tbk yang terdaftar di Bursa Efek Indonesia

Tabel 3.7

Analisis Kebijkan Dividen dan Nila

Perusahaan pada PT Kabelindo

Murni, Tbk yang terdaftar di

Bursa Efek Indonesia

Periode 2012-2016

\begin{tabular}{|c|c|c|}
\hline Tahun & $\begin{array}{c}\text { Kebijakan Dividen } \\
\text { (Kali) }\end{array}$ & $\begin{array}{c}\text { Nilai Perusahaan } \\
\text { (Kali) }\end{array}$ \\
\hline 2012 & 0,14 & 0,57 \\
\hline 2013 & 0,43 & 0,66 \\
\hline 2014 & 0,17 & 0,60 \\
\hline 2015 & $\mathbf{0 , 4 5}$ & $\mathbf{0 , 5 0}$ \\
\hline 2016 & 0,16 & 0,84 \\
\hline
\end{tabular}

Sumber : Data Diolah

Berdasarkan Tabel 3.7 terilihat bahwa kebijakan dividen dan nilai perusahaan pada PT Kabelindo Murni, Tbk yang terdaftar di Bursa Efek Indonesia Periode 2012-2016 berfluktuasi dan cenderung meningkat. Namun 
pada tahun 2015 kebijakan dividen mengalami peningkatan dan di tahun yang bersamaan nilai perusahaan mengalami penurunan.

\subsection{Evaluasi}

3.2.1. Evaluasi Likuiditas pada PT Kabelindo Murni, Tbk yang terdaftar di Bursa Efek Indonesia periode 20122016

Dari hasil analisis likuiditas, menunjukkan kondisi likuiditas pada PT Kabelindo Murni, Tbk yang terdaftar di Bursa Efek Indonesia periode 2012-2016 yang diukur dengan Current Ratio (CR) mengalami fluktuasi dan cenderung meningkat. Nilai ratarata Likuiditas pada penelitian ini adalah 1,07. Hal ini disebabkan penurunan hutang lancar lebih besar daripada penurunan aset lancar.

Untuk itu sebaiknya perusahaan menambahkan modal kerja dengan cara melakukan hutang jangka panjang untuk membeli persediaan yang dapat meningkatkan penjualan.

\subsubsection{Evaluasi Solvabilitas pada PT} Kabelindo Murni, Tbk yang terdaftar di Bursa Efek Indonesia periode 20122016

Dari hasil penelitian nilai solvabilitas mengalami fluktuasi dan cenderung menurun. Hal ini disebabkan nilai aset tetap perusahaan menurun dan secara bersamaan penjualan pada tahun 2016 meningkat namun beban yang masih harus dibayar menurun. Penurunan hutang lebih tinggi daripada penurunan total aset perusahaan. Maka dari itu sebaiknya perusahaan mengoptimalkan aset dengan cara menambah hutang agar solvabilitas dapat ditingkatkan.

3.2.3. Evaluasi Kebijakan Dividen pada PT Kabelindo Murni, Tbk yang terdaftar di Bursa Efek Indonesia periode 20122016

Dari hasil penelitian ini menunjukkan bahwa kebijakan dividen pada PT Kabelindo Murni, Tbk yang terdaftar di Bursa Efek Indonesia periode 2012-2016 yang diukur dengan Dividen Payout Ratio (DPR) mengalami fluktuasi dan cenderung meningkat. Nilai rata-rata kebijakan dividen adalah sebesar 0,27. Hal ini disebabkan oleh peningkatan dividen per lembar saham sementara terjadi penurunan laba per lembar saham juga.

Sebaiknya perusahaan meningkatkan penjualan dan mengurangi beban operasional agar laba dapat meningkat. Meningkat laba dapat meningkatkan EPS sehingga DPR dapat dikendalikan.
3.2.4. Evaluasi Nilai Perusahaan pada PT Kabelindo Murni, Tbk yang terdaftar di Bursa Efek Indonesia periode 20122016

Dari hasil penelitian ini dapat dilihat bahwa rata-rata nilai perusahaan pada PT Kabelindo Murni, Tbk yang terdaftar di Bursa Efek Indonesia periode 2012-2016 berfluktuasi dan cenderung meningkat. Nilai rata-rata nilai perusahaan periode 2012-2016 pada penelitian ini adalah 0,63. Hal ini disebabkan oleh peningkatan harga saham lebih tinggi daripada peningkatan nilai buku perusahaan.

Sebaiknya perusahaan meningkatkan laba dengan cara meningkatkan penjualan dan mengefisiensikan beban operasi. Laba yang meningkat dapat digunakan sebagai modal kerja perusahaan.

3.2.5. Evaluasi Likuiditas dan Nilai Perusahaan pada PT Kabelindo Murni, Tbk yang terdaftar di Bursa Efek Indonesia periode 2012-2016

Berdasarkan hasil analisis diketahui bahwa likuiditas berfluktuasi dan cenderung meningkat demikian juga dengan nilai perusahaan yang meningkat. Meningkatnya nilai perusahaan diikuti dengan laba pada periode penelitian cenderung menurun

Faktor yang menyebabkan adalah faktor penurunan hutang lancar yang lebih besar daripada penurunan aset lancar sementara nilai perusahaan meningkat. Harga pasar per lemabar saham mengalami peningkatan lebih tinggi daripada peningkatan di nilai buku per lembar saham yang berdampak dari pembagian dividen yang dilakukan perusahaan. Sebaiknya perusahaan menambah hutang untuk meningkatkan produktifitas penjualan yang dapat meningkatkan laba perusahaan.

3.2.6. Evaluasi Solvabilitas dan Nilai Perusahaan pada PT Kabelindo Murni, Tbk yang terdaftar di Bursa Efek Indonesia periode 2012-2016

Berdasarkan hasil analisis diketahui bahwa solvabilitas mengalami penurunan dikarenakan penurunan total hutang lebih tinggi daripada penurunan total aset sementara nilai perusahaan yang meningkat di karenakan harga saham yang meningkat lebih tinggi daripada peningkatan nilai buku per lembar saham.dan menyebabkan penurunan laba.

Karena penurunan hutang menyebabkan modal kerja menurun yang berdampak pada penurunan penjualan. Sebaiknya perusahaan mengoptimalkan aset dengan melakukan penambahan hutang yang dapat meningkatkan penjualan. 
3.2.7. Evaluasi Kebijakan Dividen dan Nilai Perusahaan pada PT Kabelindo Murni, Tbk yang terdaftar di Bursa Efek Indonesia periode 2012-2016

Berdasarkan hasil analisis diketahui bahwa kebijakan dividen dengan parameter DPR berfluktuasi dan cenderung meningkat diikuti dengan peningkatan nilai perusahaan dengan parameter PBV

Nilai perusahaan dapat menggambarkan seberapa besar pasar menghargai nilai buku saham suatu perusahaan. Semakin tinggi harga saham perusahaan maka akan semakin tinggi nilai perusahaan.

\section{KESIMPULAN DAN SARAN}

\subsection{Kesimpulan}

1. Nilai rata-rata likuiditas dengan parameter Current Ratio (CR) mengalami fluktuasi dan cenderung meningkat, namun peningkatan aset lancar diikuti dengan penurunan nilai kewajiban lancar.

2. Nilai rata-rata solvabilitas dengan parameter Debt to Asset Ratio (DAR) mengalami fluktuasi dan cenderung menurun, hal ini disebabkan penurunan hutang yang lebih tinggi daripada penurunan total aset perusahaan.

3. Kebijakan Dividen (DPR) mengalami fluktuasi dan cenderung meningkat $\mathrm{Hal}$ ini disebabkan oleh peningkatan dividen per lembar saham sementara terjadi penurunan laba per lembar saham.

4. Nilai perusahaan dengan parameter PBV mengalami fluktuasi dan cenderung meningkat, hal ini disebabkan peningkatan harga saham lebih tinggi daripada peningkatan nilai buku per lembar saham.

\subsection{Saran}

1. Sebaiknya perusahaan menambahkan modal kerja dengan cara melakukan hutang jangka panjang untuk membeli persediaan yang dapat meningkatkan penjualan.

2. Sebaiknya perusahaan meningkatkan penjualan dan mengurangi beban operasional agar laba yang didapat meningkat. Dan meningkatnya laba dapat meningkatkan EPS sehingga DPR dapat dikendalikan.

3. Sebaiknya perusahaan meningkatkan laba dengan cara meningkatkan penjualan dan mengefisiensikan beban operasi. Laba yang menigkat dapat digunakan sebagai modal kerja perusahaan

\section{DAFTAR PUSTAKA}

Arikunto, S. 2006. Metode Penelitian Kualitatif. Jakarta: Bumi Aksara.
Astuti, Dewi. 2004. Manajemen Keuangan Perusahaan. Jakarta : Graha Indonesia.

Atmaja. 2008. Manajemen Keuangan. Edisi III. Yogyakarta : Andi

Arif, 2015. Pengaruh Struktur Modal, Return on Equity, Likuiditas dan Growth Oppurtunity Terhadap Nilai Perusahaan Jasa yang terdaftar di Bursa Efek Indonesia. Yogyakarta: Universitas Negeri Yogyakarta, Skripsi

Bestariningrum, Nenggar. 2015. Analyzing the Effect of Capital Structure and Firm Size on Firm value. Manado University of Sam Ratulangi.

Brigham Eugene, F. dan Joel Houston. 2004. Dasar-Dasar Manajemen Keuangan. Edisi 10. Buku 2. Jakarta: Salemba Empat.

2006. Dasar-Dasar Manajemen Keuangan. Jakarta : Salemba Empat 2010. Dasar-Dasar Manajemen Keuangan. Edisi XI. Buku 1. Jakarta : Salemba Empat

2011. Dasar-Dasar Manajemen Keuangan. Edisi XI. Buku 2. Jakarta : salemba empat

2012. Dasar-Dasar Manajemen

Keuangan. Jakarta : Salemba Empat

Bursa Efek Indonesia. http://www.idx.co.id. Tahun akses 2018.

Fau, Nia Rositawati, 2015. Pengaruh Struktur Modal, Pertumbuhan Perusahaan, Ukuran Perusahaan, dan Profitabilitas terhadap Nilai Perusahaan. Universitas Yogyakarta, Skripsi.

Hery. 2015. Analisis Laporan Keuangan. Edisi I. Jakarta : Centre For Academic Publishing Sevices.

Horne, James C.Van dan John M. Wachowicz. 2012. Prinsip-Prinsip Manajemen Keuangan. Edisi XIII. Buku 1. Jakarta : Salemba Empat.

2013. Prinsip-Prinsip Manajemen Keuangan. Edisi XIII. Buku 2. Jakarta : Salemba Empat.

Kasmir. 2010. Pengantar Manajemen Keuangan. Jakarta : Kencana

2015. Pengantar Manajemen Keuangan. Jakarta : Kencana

Keown, et,al. 2008. Manajemen Keuangan. Edisi X. Jilid 1. Jakarta : Indeks.

Martani, Dwi, Dkk. 2012. Akuntansi Keuangan Menengah berbasis PSAK, Buku Satu. Jakarta: Salemba Empat.

Munawir, S. 2004. Analisis Laporan Keuangan. Edisi IV. Yogyakarta : Liberty

Murhadi, Werner R. 2013. Analisis Laporan Keuangan, Proyeksi dan Valuasi Saham. Jakarta : Salemba Empat. 
Murtianingsih, 2012. Pengaruh Determinan Struktur Modal Terhadap Nilai Perusahaan (Studi Kasus Pada Perusahaan Properti di BEI). Jurnal. UMM.

Mursyidi. 2010. Akuntansi Dasar, Cetakan 1. Bogor: Ghalia Indonesia.

Rudianto. 2009. Pengantar Akuntansi. Jakarta : Erlangga.

2012. Pengantar Akuntansi Konsep dan Teknik Penyusunan Laporan Keuangan. Jakarta : Erlangga.

2013. Akuntansi Manajemen

Informasi Untuk Pengambilan

Keputusan Strategis. Jakarta : Erlangga.

Riyanto, Bambang. 2009. Dasar-Dasar Pembelanjaan Perusahaan. Yogyakarta : BPFE.

Septia, Ade Winda. 2015. Pengaruh Profitabilitas, Keputusan Investasi, Keputusan Pendanaan, dan Kebijakan Dividen Terhadap Nilai Perusahaan Pada Perusahaan Manufaktur Yang Terdaftar di BEI. Universitas Negeri Yogyakarta, Skripsi.

Simbolon, Hotman. 2009. Statistika. Yogyakarta : Graha IImu.

Soemarso,S.R.2004. Akuntansi Suatu Pengantar. Edisi V. Buku 1. Jakarta: Salemba Empat.

Sri, Ayu Mahatma Dewi dan Ari Wirajaya, 2013. Pengaruh Struktur Modal, Profitabilitas, dan Ukuran Perusahaan terhadap Nilai Perusahaan. Universitas Udayana Bali, Skripsi.

Subramanyam, K. R dan John J. Wild. 2010. Analisis Laporan Keuangan : Financial Statement Analysis. Edisi X. Buku 1. Jakarta : Salemba Empat.

Sudana, I Made. 2011. Manajemen Keuangan Perusahaan Teori dan Praktik. Jakarta : Erlangga.

Wulan, 2017. Analisis Pengaruh Struktur Modal, Profitabilitas, dan Ukuran Perusahaan Terhadap Nilai Perusahaan Manufaktur di BEI. Universitas Muhammadiyah Surakarta, Skripsi. 